\title{
Molecular genotypes analysis of Cryptosporidium and Hymenolepis in rats on Lombok Island, Indonesia
}

\author{
Ersandhi Resnhaleksmana1(D), Wayan Tunas Artama² (D), Mahardika Agus Wijayanti ${ }^{(\mathbb{D}}$ and Fihiruddin Fihiruddin ${ }^{4}$ (i)
}

1. Doctoral Program, Faculty of Medicine, Public Health and Nursing, Universitas Gadjah Mada, Yogyakarta, Indonesia; 2. Department of Biochemistry, Faculty of Veterinary Medicine, and One Health/Ecohealth Resource Center, Universitas

Gadjah Mada, Yogyakarta, Indonesia; 3. Department of Parasitology, Faculty of Medicine, Public Health and Nursing,

Universitas Gadjah Mada, Yogyakarta, Indonesia; 4. Department of Medical Laboratory Technology, Politeknik Kesehatan Mataram, Indonesia.

Corresponding author: Ersandhi Resnhaleksmana, e-mail: resnha@gmail.com

Co-authors: WTA: artama@ugm.ac.id, MAW: mahardikaaw@ugm.ac.id, FF: fihir.analis@yahoo.co.id Received: 10-06-2020, Accepted: 04-08-2020, Published online: 08-09-2020

doi: www.doi.org/10.14202/IJOH.2020.123-127 How to cite this article: Resnhaleksmana E, Artama WT, Wijayanti MA, Fihiruddin F (2020) Molecular genotypes analysis of Cryptosporidium and Hymenolepis in rats on Lombok Island, Indonesia, Int. J. One Health, 6(2): 123-127.

\begin{abstract}
Background and Aim: Cryptosporidium parvum and Hymenolepis nana are intestinal parasites that are commonly found in the unclean environment. Their presence in rats promotes the transmission of the cryptosporidiosis and hymenolepiasis to humans or animals nearby. This study aimed to determine the molecular characteristics of C. parvum and $H$. nana and their distribution in rats on Lombok Island.
\end{abstract}

Materials and Methods: C. parvum and H. nana were investigated in 50 rats from Lombok Island. The molecularparasitological technique used was polymerase chain reaction and sequencing method.

Results: From 50 samples of rats' stool from 10 locations on Lombok Island, 8\% (4/50) of C. parvum was detected molecularly with an $18 S$ rRNA gene and 2\% (1/50) of $H$. nana with COX 1 gene. Phylogenetic analysis indicated that C. parvum carrying rats on Lombok Island have a genetic relationship with C. parvum with Obi7 isolates, Japan and $H$. nana has a genetic relationship with Rodentolepis nana identified with Hn-VT isolates, India.

Conclusion: The highest incidence of parasites was found in rats that were caught in the urban areas of Lombok Island, West Nusa Tenggara, Indonesia. Immediately, public health programs in these types of contaminated areas should receive priority attention to prevent further transmission of the parasites from animals to human beings.

Keywords: Cryptosporidium, Hymenolepis, intestinal parasite, Rattus.

\section{Introduction}

Diarrhea is a common global disease in both developed and developing countries. The cause of diarrhea generally occurs due to bacterial, fungal, viral, or parasitic infection. Diarrhea if not resolved properly, can cause death and become a significant burden on a country's economic development as well as medical resources. Parasites are one group of pathogens that contribute to diarrhea in developing countries and countries with low economic level. The digestive tract parasites are commonly found in third world countries, especially with tropical climates. The transmission can occur by any kind of animal, and rats are one common carrier $[1,2]$.

Major changes in the natural habitat by humans cause human contact with animals to become more frequent. Diseases related to rats (rodent-borne diseases) began to increase in line with changes in the natural habitat. A rat

Copyright: Resnhaleksmana, et al. This article is an open access article distributed under the terms of the Creative Commons Attribution 4.0 International License (http://creativecommons.org/ licenses/ by/4.0/), which permits unrestricted use, distribution, and reproduction in any medium, provided you give appropriate credit to the original author(s) and the source, provide a link to the Creative Commons license, and indicate if changes were made. The Creative Commons Public Domain Dedication waiver (http:// creativecommons.org/ publicdomain/zero/1.0/) applies to the data made available in this article, unless otherwise stated. can act as a transmitter of infectious diseases due to their habitat and habits which are usually scavenging food in dirty places with garbage and consuming water contaminated with diseases so that the rats can cause transmission to not only humans but also animals [3].

Rats can carry various infectious diseases, both groups of viruses, bacteria, and parasites. Infectious diseases could be transmitted to humans through the saliva, urine, and stool or the ectoparasite bites. The dissemination of zoonotic parasites from rats to the human environment requires identification through an early investigation of the zoonotic parasite transmission source. The proximity of the rats with the human environment can be a risk factor for parasite transmission from rats to humans. Parasites can be transmitted through the digestive tract and the infected rats can then cause digestive tract disorders in humans. Parasites of the gastrointestinal tract from rats that have been reported to infect humans include the following, among others: Hymenolepis nana, Giardia lamblia, Balantidium coli, Angiostrongylus cantonensis, Trichuris spp., Enterobius vermicularis, and Cryptosporidium spp. [4-7].

Seventy-five million people of the world's population are estimated to be carriers of $H$. nana, and the highest incidence rates can reach up to $25 \%$ in some places. Research in Rio de Janeiro, Uttarakhand, 
North England, and Kuala Lumpur reported that $H$. nana is commonly found in unclean environments and where are many rats. $H$. nana commonly infects primary school-age children even with clean living habits [8-11].

$H$. nana infection was also found in $35 \%$ of the 17 rats in the plantation areas of Lampung with microscopic examination. Molecular identification used ITS- 1 gene in 35 adult cestode worms of rats in Lombok and identified two samples of $H$. nana and one of $H$. diminuta $[12,13]$.

Cryptosporidium is an intestinal tract protozoan which can be transmitted through the stool of rats. Infections caused by Cryptosporidium can cause moderate to severe diarrhea and even death in children under 2 years old and people who are immunocompromised [14]. Cryptosporidium was found to have a high prevalence of $22.5 \%$ (14/62) in immunocompromised children, with microscopic and polymerase chain reaction (PCR) examination [15]. Cryptosporidium was reported in $12.7 \%(23 / 180)$ of Rattus rattus and Rattus norvegicus in Iran using the Ziehl-Neelsen staining [16]. Molecular examination using a small subunit $r R N A$ gene could identify the presence of Cryptosporidium parvum and Cryptosporidium muris in rats in China. C. parvum subtype 11dA15G1 that infects humans was identified after gene sequencing using $g p 60[17,18]$.

This study aimed to determine the molecular characteristics of $C$. parvum and $H$. nana and their distribution in rats on Lombok Island, Indonesia.

\section{Materials and Methods}

\section{Ethical approval and informed consent}

This study was approved by the Medical and Health Research Ethics Committee of the Faculty of Medicine, Public Health and Nursing, Gadjah Mada University-Dr. Sardjito General Hospital, with approval number: KE/FK/1222/EC/2018, dated November 21, 2018. Informed consent was obtained from all individual participants included in the study.

\section{Study period, area and sample collection}

Fifty samples of rats were caught from five districts in Lombok Island, West Nusa Tenggara Province, from July to November 2019. Sampling was carried out purposively in a tourist-residential area. Each district provided 10 points for each sampling location of rats: Mataram, East Lombok, Central Lombok, West Lombok, and North Lombok. Samples of rat stool were obtained from rat cecum, and DNA of parasites was obtained by extraction used reagents and procedures QIAamp, Fast DNA Stool Mini Kit (Qiagen, Germany).

\section{Parasitological examination technique}

DNA extraction, $200 \mathrm{mg}$ of the stool, was mixed with $1 \mathrm{~mL}$ InhibitEX Buffer divortex until homogeneous. The lysis process was done by incubating samples in a water bath at a temperature of $85^{\circ} \mathrm{C}$ for $5 \mathrm{~min}$.
Samples were centrifugated at $10,000 \mathrm{rpm}$ for $1 \mathrm{~min}$ to obtain a supernatant. Then, the supernatant as much as $600 \mu \mathrm{L}$ was added with $25 \mu \mathrm{L}$ of protein $\mathrm{K}$, then combined with $600 \mu \mathrm{L}$ of buffer $\mathrm{AL}$ and incubated at $70^{\circ} \mathrm{C}$ for $10 \mathrm{~min}$. To get lysates, $600 \mu \mathrm{L}$ of ethanol $96-100 \%$ was added. After transferring the $600 \mu \mathrm{L}$ of lysate into the spin column, centrifugated at $10,000 \mathrm{rpm}$ for $1 \mathrm{~min}$, the filtrate was removed and placed in $2 \mathrm{~mL}$ tube. A back up of all lysate leftover was made and combined with $500 \mu \mathrm{L}$ of buffer AW1 into the spin column with a new collection tube, centrifugated at $10,000 \mathrm{rpm}$ for $1 \mathrm{~min}$, the filtrate was removed. Next, $500 \mu \mathrm{L}$ of buffer AW 2 was added in a new collection tube and centrifugated at 10,000 rpm for $3 \mathrm{~min}$. After removing the spin column from the collection tube, it was installed in a new collection tube and centrifugated at 10,000 rpm for $3 \mathrm{~min}$. Then, it was transferred from the spin column into $1.5 \mathrm{~mL}$ tube, then $100-200 \mu \mathrm{L}$ of buffer ATE was added into the spin column and let stand $1 \mathrm{~min}$ to dissolve the DNA and finally centrifugated at 10,000 rpm for $1 \mathrm{~min}$. After discarding the spin column, the $1.5 \mathrm{~mL}$ tube which contained DNA was stored at $-20^{\circ} \mathrm{C}$.

PCR amplification and detection, PCR as a determinant of DNA used Bioline mix with $0.2 \mathrm{~mL}$ PCR tube containing $2 \mathrm{~mL}$ DNA template DNA, $6.5 \mu \mathrm{L}$ of ultrapure water, and $12.5 \mu \mathrm{L}$ Master Mix in $2 \times 2 \mu \mathrm{L}$. Primers used were $C$. parvum 18S Ribosomal RNA gene primer[19]F:5' -TAAACGGTAGGGTATTGGCCT-3'; R:5'-CAGACTTGCCCTCCAATTGATA-3'; H. nana gene cytochrome oxidase subunit 1 (COX1) [20,21], F:5'AGGTTGTAGTGTGTGGGCTC-3'; R:5' CCAGTCACACCACCAAATCT-3'. PCR conditions used were 35 cycles, with initial activation temperature $95^{\circ} \mathrm{C}$ for $5 \mathrm{~min}$, a temperature of $95^{\circ} \mathrm{C}$ for $30 \mathrm{~s}$ denaturation, annealing temperature of $59^{\circ} \mathrm{C}$ for $45 \mathrm{~s}$, extension temperature $72^{\circ} \mathrm{C}$ for $3 \mathrm{~min}$, and a final extension temperature of $72^{\circ} \mathrm{C}$ for $10 \mathrm{~min}$. The final results were identified using electrophoresis on agarose $2 \%$ [22].

Sequencing, the analysis of the parasite's genetic relationship was done by phylogenetic test, with sample DNA amplification product followed by purification and sequencing. Sequencing used an Applied Biosystems 3500 Genetic Analyzer 2500 with BigDye Terminator kit. Edited DNA parasite sequencing used ClustalW Molecular Evolutionary Genetics Analysis (MEGA) software version 10, USA. The phylogeny tree was based on neighbor-joining [23-26].

\section{Results}

PCR examination of rats' stool samples on Lombok Island indicated the presence of $C$. parvum and $H$. nana. The results are shown in the following table, which shows four samples of $C$. parvum and one of $H$. nana were identified from the 50 samples of rats. Confirmation was done by molecular PCR examination followed by electrophoresis, namely, C. parvum at $240 \mathrm{bp}$ and $H$. nana at $216 \mathrm{bp}$, in Table-1 and Figure- 1 . 
C. parvum phylogenetic analysis used $18 S r R N A$ gene and $H$. nana used $C O X 1$ to examine and determine the genetic relationship. The analysis of the parasites' genetic relationship used the "NeighborJoining" method. Each gene sequence was based on the access available in GenBank. The consensus of the bootstrap tree concluded 1000 replications, and evolution of parasites' distance was calculated based on the method of "Kimura 2." All calculations were performed by phylogenetic analysis using the free software of "MEGA X," USA [23-26].

C. parvum in rats caught on Lombok Island has a monophyletic kinship with C. parvum (FJ796268.1) in Japan and kinship synapomorphic with $C$. suis (AB694726.1 and AB449828) in Japan, as shown in Figure-2.

Table-1: The location of rats infected with Cryptosporidium parvum and Hymenolepis nana.

\begin{tabular}{lcc}
\hline District/City & \multicolumn{2}{c}{ Parasite } \\
\cline { 2 - 3 } & $\begin{array}{c}\text { Cryptosporidium } \\
\text { parvum }\end{array}$ & $\begin{array}{c}\text { Hymenolepis } \\
\text { nana }\end{array}$ \\
\hline Mataram & + & - \\
East Lombok & - & + \\
Central Lombok & + & - \\
Lombok Barat & - & - \\
North Lombok & + & - \\
\hline
\end{tabular}

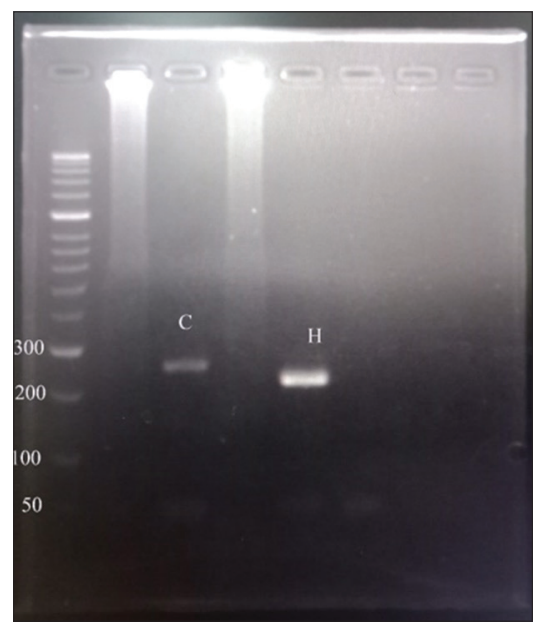

Figure-1: "C," the results of electrophoresis sample DNA Cryptosporidium parvum with the primer 185 Ribosomal RNA gene and " $\mathrm{H}$," the results of electrophoresis sample DNA Hymenolepis nana with the primer COX1.

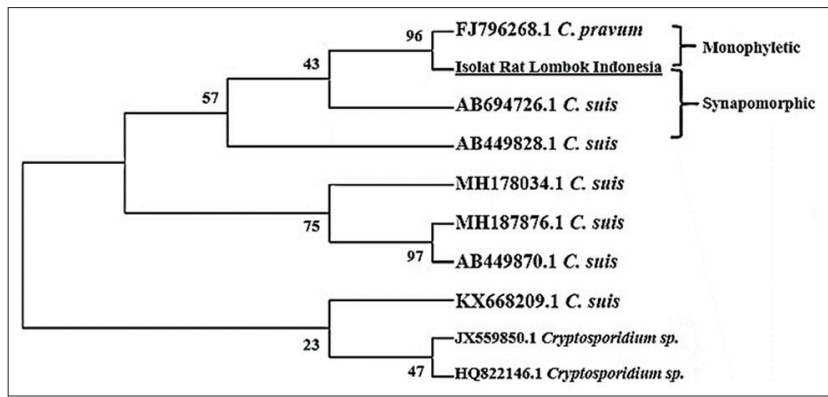

Figure-2: Cryptosporidium parvum phylogenetic trees based on gene sequences $18 S$ Ribosomal RNA, kinship analyzed using the method of "Neighbor-Joining."
H. nana in rats caught on Lombok Island, West Nusa Tenggara, has a monophyletic kinship with Rodentolepis nana (KU821727.1) in India and synapomorphic kinship with H. nana (AY121842.1) and Taenia spp. (AB905203.1) in Ethiopia, as shown in Figure-3.

The dissemination of $C$. parvum and H. nana in urban shown in Figure-4. The dissemination of Cryptosporidium parasite was more than H. nana. C. parvum was found in rats caught in Pemenang Village, North Lombok District, Ampenan and Mataram, Pujut Village in Center Lombok, while $H$. nana was found only in rats which were caught in Selong, East Lombok District, as shown in Figure-4.

\section{Discussion}

C. parvum was most identified in rats which were caught on the Lombok Island, involving $8 \%$ of carriers of C. parvum of the 50 rats caught on the Lombok Island. Cryptosporidium is a parasite in animals able to infect humans and can cause diarrhea. One of the worms contained in rats that could infect humans and cause diarrhea is $H$. nana. Severe infections can cause diarrhea in children and obstruct their development. According to genotyping, from the rats caught on the Lombok Island, there was only one sample with $H$. nana.

Cryptosporidiosis has been reported in a previous study in the farm areas of the Algerian population. Using microscopic methods with formyl-ether concentration and Ziehl-Neelsen staining, Cryptosporidium was found in moderately high incidence: $36.7 \%$ in cattle, sheep $15 \%, 8.9 \%$ of broiler chickens, and $2 \%$ in camels. The incidence of cryptosporidiosis was increased to $52.6 \%$ in calves with diarrhea [27]. Cryptosporidium was also reportedly found in wild rats caught in the area of Hainan, China. The results of PCR analysis using a small subunit of ribosomal DNA gene found $50 \%$ of rats infected by Cryptosporidium from 150 rats which were caught [18]. C. parvum was also reportedly found in two Rattus spp. among 134 rats that were used as laboratory rats, which was detected using PCR of $18 \mathrm{~S}$ $r R N A$ gene [2]. H. nana is a tapeworm commonly found in rats, and human transmission is caused by unclean living habits, so the embryonated eggs or cysticercoids become swallowed. Several countries have reported the incident of hymenolepiasis, including the

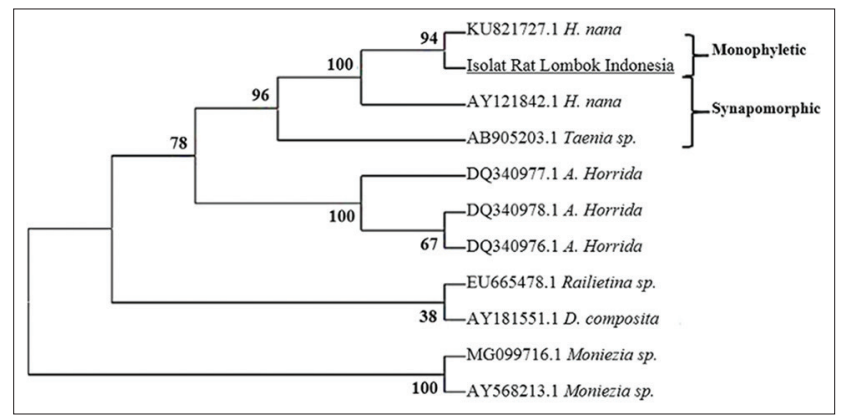

Figure-3: The phylogenetic tree of Hymenolepis nana based on gene sequences cytochrome oxidase subunit 1, kinship analyzed using the method of "Neighbor-Joining." 


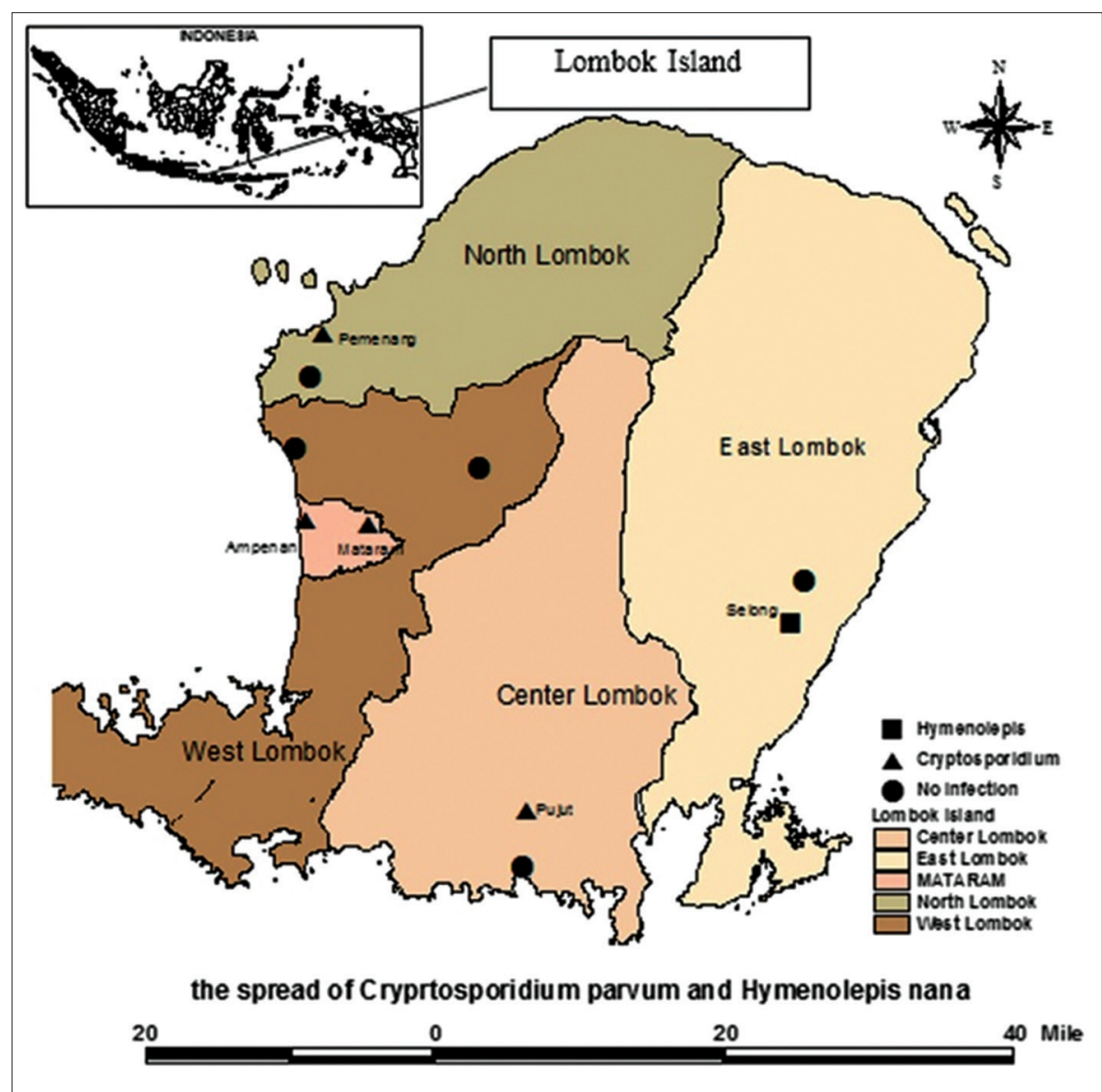

Figure-4: The location of the spread of Cryptosporidium parvum and Hymenolepis nana in rats on Lombok Island (Source: https://tanahair.indonesia.go.id/portal-web )

discovery of $H$. nana in Ethiopia that infected a pregnant women and severe infections with symptoms of abdominal pain, nausea, and diarrhea; the discovery of anemia in Bolivian children infected by parasites and identified as $H$. nana [28,29].

Gene molecular analysis used $C O X 1$ against rats on Lombok Island, and there was one rat identified with hymenolepiasis out of the 50 rats which were caught. Molecular studies were used in Iraq against $R$. rattus and found $4 \%$ of rats infected with $H$. nana while in Iran, there was $H$. nana infection detection of $0.65 \%$ in the study population $[30,31]$.

Cryptosporidium and Hymenolepis that were detected on Lombok Island tended to be widely identified in rats caught in urban areas. Parasites generally are found in a congested area with an unclean environment. Cryptosporidium and Hymenolepis which were found in rats can be transmitted to humans or animals nearby. One research report in Bolivia showed a high risk of anemia in children of school age who were infected by $H$. nana. Continued infection over long periods of time can diminish the performance index and degrade child development [28]. Cryptosporidium infections that cause diarrhea were found in as many as $37 \%$ of the 300 samples of diarrhea in Egypt. Patients suspected of cryptosporidiosis should be treated immediately since prolonged infection has been proven fatal in some patients who are immunocompromised. Research recently has shown that the most serious impact is on children or people living with HIV/AIDS [32].

\section{Conclusion}

The highest incidence of parasites was found in rats which were caught in the urban areas of Lombok Island, West Nusa Tenggara. Immediately, public health programs in these types of contaminated areas should receive priority attention to prevent further transmission of the parasites.

\section{Authors' Contributions}

ER, WTA, and MAW designed the research study. ER, WTA, and FF gathered the data from the field. ER, WTA, and MAW interpreted the results and analyzed the data. ER, WTA, and MAW prepared the manuscript. All authors read and approved the final manuscript.

\section{Acknowledgments}

The authors would like to extend their thanks to the Faculty of Veterinary Medicine, and One Health/ Ecohealth Resource Center, Universitas Gadjah Mada, Yogyakarta, Indonesia, for funding this study and their staff who assisted the researchers in the sample collection.

\section{Competing Interests} interests.

The authors declare that they have no competing 


\section{Publisher's Note}

Veterinary World (Publisher of International Journal of One Health) remains neutral with regard to jurisdictional claims in published map and institutional affiliation.

\section{References}

1. Adam, E.A., Yoder, J.S., Gould, L.H., Hlavsa, M.C. and Gargano, J.W. (2016) Giardiasis outbreaks in the United States, 1971-2011. Epidemiol. Infect., 144(13): 2790-2801.

2. Ayinmode, A.B., Ogbonna, N.F. and Widmer, G. (2017) Detection and molecular identification of Cryptosporidium species in laboratory rats (Rattus norvegicus) in Ibadan, Nigeria. Ann. Parasitol., 63(2): 105-109.

3. Morand, S. (2015) Global parasite and Rattus rodent invasions: The consequences for rodent-borne diseases. Integr. Zool., 10(5): 267-281.

4. Zahedi, A., Paparini, A., Jian, F., Robertson, I. and Ryan, U. (2016) Public health significance of zoonotic Cryptosporidium species in wildlife: Critical insights into better drinking water management. Int. J. Parasitol. Parasites Wildl., 5(1): 88-109.

5. Azzam, K.M. and El-Abd, N.M. (2016) Survey of endoparasites of different rodent species in Egypt. Egypt. J. Biol. Pest Control, 26(4): 815-820.

6. Zahedi, A., Field, D. and Ryan, U. (2017) Molecular typing of Giardia duodenalis in humans in Queensland first report of assemblage e. Parasitology, 114(9): 1154-1161.

7. Gordo, P. and Pomajbíková, J. (2017) Balantidium coli. In: Fayer, R. and Jakubowski, W. editors. Global Water Pathogen Project. Michigan State University, E Lansing, MI, UNESCO. Available from: https://www.waterpathogens. org/sites/default/files/Balantidium\%20coli1.pdf. Retrieved on 15-08-2020.

8. Crompton, D.W.T. (1999) How much human helminthiasis is there in the world? J. Parasitol., 85(3): 397-403.

9. Mirdha, B.R. and Samantray, J.C. (2002) Hymenolepis nana: A common cause of paediatric diarrhoea in urban slum dwellers in India. J. Trop. Pediatr., 48(6): 331-334.

10. Zain, S.N.M., Amdan, S.A.S., Braima, K.A., AbdulAziz, N.M., Wilson, J.J., Sithambaran, P. and Jeffery, J. (2015) Ectoparasites of murids in peninsular Malaysia and their associated diseases. Parasit. Vector, 8(1): 254.

11. Simões, R.O., Luque, J.L., Gentile, R., Rosa, M.C.S., Costa-Neto, S. and Maldonado, A. (2016) Biotic and abiotic effects on the intestinal helminth community of the brown rat Rattus norvegicus from Rio de Janeiro, Brazil. J. Helminthol., 90(1): 21-27.

12. Dewi, K. and Purwaningsih, E. (2014) Helminth parasites on rats in rubber plantation in Bogorejo Village, Gedongtataan Subdistrict, Pesawaran Regency, Lampung and their zoonotic review. Zoo Indones., 22(2): 1-7.

13. Tresnani, G., Suana, I.W. and Hadi, I. (2016) The detection of Hymenolepis sp. from house rats (Rattus rattus diardii Jentink, 1880) in Mataram through ITS-1 gene PCR analysis. AIP Conf. Proc., 1744(1-4): 20023.

14. Certad, G., Viscogliosi, E., Chabé, M. and Cacciò, S.M. (2017) Pathogenic mechanisms of Cryptosporidium and Giardia. Trends Parasitol., 33(7): 561-576.

15. Caner, A., Zorbozan, O., Tunal1, V., Kantar, M., Aydoğdu, S., Aksoylar, S. and Turgay, N. (2019) Intestinal protozoan parasitic infections in immunocompromised child patients with diarrhea. Jpn. J. Infect. Dis., 73(3): 187-192.

16. Mirzaghavami, M., Sadraei, J. and Forouzandeh, M. (2016) Detection of Cryptosporidium spp. in free ranging animals of Tehran, Iran. J. Parasit. Dis., 40(4): 1528-1531.

17. Zhao, Z., Wang, R., Zhao, W., Qi, M., Zhao, J., Zhang, L., Li, J. and Liu, A. (2015) Genotyping and subtyping of
Giardia and Cryptosporidium isolates from commensal rodents in China. Parasitology, 142(6): 800-806.

18. Zhao, W., Zhou, H., Huang, Y., Xu, L., Rao, L., Wang, S., Wang, W., Yi, Y., Zhou, X., Wu, Y. and Ma, T. (2019) Parasites and wildlife Cryptosporidium spp. in wild rats (Rattus spp.) from the Hainan Province, China: Molecular detection, species/genotype identification and implications for public health. Int. J. Parasitol., 9(1): 317-321.

19. Zebardast, N., Yeganeh, F., Gharavi, M.J., Abadi, A., Tabaei, S.J.S. and Haghighi, A. (2016) Simultaneous detection and differentiation of Entamoeba histolytica, E. dispar, E. moshkovskii, Giardia lamblia and Cryptosporidium spp. in human fecal samples using multiplex PCR and qPCR-MCA. Acta Trop., 162(233-238): 233-238.

20. Hailemariam, Z., Nakao, M., Menkir, S., Lavikainen, A., Yanagida, T., Okamoto, M. and Ito, A. (2012) Molecular identification of unilocular hydatid cysts from domestic ungulates in Ethiopia: Implications for human infections. Parasitol. Int., 61(2): 375-377.

21. Di Yang, W.Z., Zhang, Y. and Liu, A. (2017) Prevalence of Hymenolepis nana and $H$. diminuta from brown rats (Rattus norvegicus) in Heilongjiang Province, China. Korean $J$. Parasitol., 55(3): 351.

22. Nkouawa, A., Haukisalmi, V., Li, T., Nakao, M., Lavikainen, A., Chen, X., Henttonen, H. and Ito, A. (2016) Parasitology international cryptic diversity in hymenolepidid tapeworms infecting humans. Parasitol. Int., 65(2): 83-86.

23. Saitou, N. and Nei, M. (1987) The neighbor-joining method: A new method for reconstructing phylogenetic trees. Mol. Biol. Evol., 4(4): 406-425.

24. Felsenstein, J. (1985) Confidence limits on phylogenies: An approach using the bootstrap. Evolution, 39(4): 783-791.

25. Kimura, M. (1980) A simple method for estimating evolutionary rates of base substitutions through comparative studies of nucleotide sequences. J. Mol. Evol., 16(2): 111-120.

26. Kumar, S., Stecher, G., Li, M., Knyaz, C. and Tamura, K. (2018) MEGA X: Molecular evolutionary genetics analysis across computing platforms. Mol. Biol. Evol., 35(6): 1547-1549.

27. Laatamna, A.K., Belkessa, S., Khalil, A., Afidi, A., Benmahdjouba, K., Belalmi, R., Benkrour, M., Ghazel, Z., Hakem,A. andAissi, M. (2018) Prevalence of Cryptosporidium spp. in farmed animals from steppe and high plateau regions in Algeria. Trop. Biomed., 35(3): 724-735.

28. Spinicci, M., Macchioni, F., Gabrielli, S., Rojo, D., Gamboa, H., Villagrán, A.L., Vallejos, Y., Strohmeyer, M., Roselli, M., Cancrini, G. and Olliaro, P. (2018) Hymenolepis nana an emerging intestinal parasite associated with anemia in school children from the Bolivian Chaco. Am. J. Trop. Med. Hyg., 99(6): 1598-1601.

29. Kandi, V., Koka, S.S. and Bhoomigari, M.R. (2019) Hymenolepiasis in a pregnant woman: A case report of Hymenolepis nana infection. Cureus, 11(1): e3810.

30. Nabeel, M. and Al-Tameemi, M. (2019) Comparative study morphological and molecular for infected rodent with two cestoda Hymenolepis nana and $H$. diminuta in Al-Diwaniyah City, South of Iraq. J. Phys. Conf. Ser., 124(6): 62058.

31. Shahnazi, M., Mehrizi, M.Z., Alizadeh, S.A., Heydarian, P., Saraei, M., Alipour, M. and Hajialilo, E. (2019) Molecular characterization of Hymenolepis nana based on nuclear rDNA ITS2 gene marker. Afr. Health Sci., 19(1): 1346-1352.

32. Gabr, N.S., Ahmed, A.K., Belal, U.S., Abd Rabou, R.A.M., Ahmed, R.F. and Abdel-Hafeez, E.H. (2019) Molecular characterization of Cryptosporidium isolates from humans by nested polymerase chain reaction-restriction fragment length polymorphism (nPCR-RFLP) analysis in Egypt. Trop. Biomed., 36(1): 1-10. 